\title{
The Problem of Universal Grammar with Multiple Languages: Arabic, English, Russian as Case Study
}

\author{
Nabeel Imhammed Zanoon \\ Department of Applied Science, Al- Balqa' Applied University (BAU) \\ Aqaba-Jordan
}

\begin{abstract}
Every language has its characteristics and rules, though all languages share the same components like words, sentences, subject, verb, object and so on. Nevertheless, Chomsky suggested the theory of language acquisition in children instinctively through a universal grammar that represents a universal grammar for all human languages. Since it has its declaration, this theory has encountered criticism from linguists. In this paper, the criticism will be presented, and the conclusion that the general rule is not compatible with all human languages will be suggested by studying some human languages as a case namely Arabic, English, and Russian.
\end{abstract}

Keywords-Chomsky; linguistic; Universal Grammar; Arabic; English; Russian

\section{INTRODUCTION}

All languages contain in their structure of the categories of the word, a noun and a verb. However, there is a difference through the category of open-class words such as nouns, verbs, and adjectives, which are regarded as the foundation stone in the formation of sentences in a language, while the categories of the closed-class words consist of the articles, conjunctions as well as prepositions. These words are empty of meaning [1]. Their abstract form which demonstrates the meaning of the phrase represents the deep structure while the surface structure is what we write and say. However, there is a relationship of transformations between them such as combination, addition, and deletion. Chomsky has presented transformational rules which he built on the duality of linguistic structure [2].

Philosophers and psychologists started since the twentiethcentury research in the phenomena of language learning and mastery. It became obvious that knowledge of the language does not depend only on the connection between the words; it is made up by knowing how to put words together because language is made up of sentences that express our thoughts. If the knowledge of a language is acquired by knowing all the mysterious rules, a question is raised on how children can learn complex rules in language [3]. Linguists believe that the sentence is the basic structure and characteristic of the human language as all human languages are made up by of syntactic patterns. A Syntactic pattern is a model which identifies human language. Chomsky, in 1972, showed that human beings had a language acquisition device and put forward the Universal Grammar (UG) theory [4]. This is a comprehensive grammar theory which assumes that there are general rules common to all languages. It explains the principles of language acquisition , and it is not concerned with describing specific languages [5], due to the fact that universal rules show that children use them to understand and acquire their mother tongue because they stipulate that the universal rules are rules for all languages [6]. The language acquisition device is called Universal Grammar which provides children with the principles of a universal language and grammatical structures with an instinctive hypothesis; it suggests that our ability to learn language rules is already found in the brain. This theory states that language ability appears by itself without being taught and that there are characteristics common to all human languages [7]. The problem of the universal grammar with other languages will be discussed by studying the syntactic structure in several languages and comparing them to each other, and by designing a finished cases device that represents the structure and arrangement of words in the languages in order to prove that each language is specific in the linguistic structure and word order, and any change in that leads to a difference in meaning. Moreover, some of the criticism by linguists will be discussed and cited to support the idea put forward in this paper.

\section{RELATED WORK}

In [8] showed in his study that the universal grammar is a suspected, and that the evidences put forward are weak, since there are some arguments in favor of the general rules without any evidence to support them, but there is no general model for general rules. They are a set of proposals, with a presentation of the views of some researchers and scientists, including, that child language learning and development varies from child to child in terms of syntax. In his paper, he stated that the general rules, in fact, do not exist, and presented a series of criticisms from different sources.

In [9] showed in his study that Chomsky's hypothesis was not widely accepted, and that it is just a theory, citing Piaget that the hypothesis is contrary to the truth, because knowledge acquisition is through experience and work. He said that if the language learning is a simple acquisition process from childhood, the child will not be in need of learning anything related to language.

He denied that the universal grammar is innate, and illustrated this by several examples. He concluded that learning the grammatical rules is endless, since languages have infinite probabilities in the formation of sentences and learning languages, that is to say, children may take a long time to learn the language rules in order to stop committing grammatical errors. 


\section{GENERAL RULES AND HUMAN LANGUAGES}

The human languages consist of letters, words and sentences. Each language has its special script and terminology, for all languages consist of nominal and verbal sentences, and these sentences include a noun which functions as the subject, object or case. What regulates and adjusts the sentences and word order in language is the language rules, and each language has its rules and word order. Language is generated through an input of words, groups of words and sentences, and in order to produce sentences that represent language the input must be processed, and through the application of the rules, the output will be compatible with the input as in Fig (1).

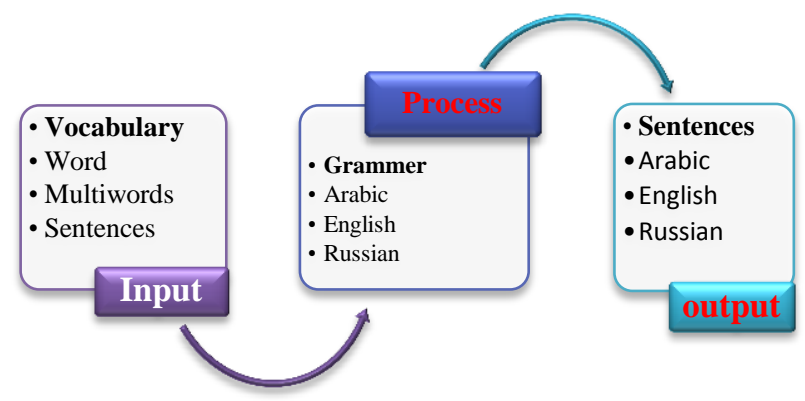

Fig. 1. The system to understand language

For example, if the input is in Arabic, can you process the input by the rules of the English language or any other language, and would the output be in Arabic or English? If we took an Arab child from birth and made him live with two boys who speak English and live in a country that speaks English, will he speak the Arabic or the English Language? Of course, he will speak English because the input was in English and through the linguistic application which accompanies a child's growth the rules of the English language will gradually be applied, and the output will consequently be in English.

We go back to the previous example of the Arab child if we apply the universal grammar theory what the output of the child will be? Based on the text of the theory, the child will speak Arabic because he acquires language and rules by instinct, that is, through the device of comprehensiveness of language found in the brain, regardless of input from the environmental.

\section{ACQUISITION PROCESS}

With the increasing vocabulary of the child, it is believed that he is somehow taught the language which means that children are using what is said to build possible ways to use the language. The linguistic production of children shows that it is often a kind of an experience or test for some structures as to whether they were correct or not. One of the factors that appear to be important in the process of a child acquisition of language is the actual use of sounds and words, whether in communicating with others or in dealing with words alone.

The human system, just like a computer system, consists of input, processing and output; language acquisition by children takes place by mingling and communicating, for conversation and dialogue are kinds of input. Processing takes place in the brain and outputs through language, that is, conversation and dialogue. Eyesight is also regarded a sort of input, and the processing takes place in the brain while the output is done through behavior and other matters such as touch. The brain does not create something out of nothing but it has some processes depending on the input the proof is that if we put a child in isolation from humans beginning from the first month to the age of 3 or 4 years, will he speak any language, and from where will he acquire the language? So the child's brain does not contain a linguistic device that automatically generates language.

Language is made up of sentences composed of words, and the child stores a large number of words and through dialogue sentences are structured out of these words. Sentences are made by dictating orders; for example, if a child stored several words such as door, open, come, here, box, book ... etc., he will receive the sentences in the form of order 'come here', and upon hearing these sentences, he will obey the order. In this way, these sentences become compound ones. In case he wants to speak to someone else he will say 'come here' and a few sentences are made that way, and so the child learns the language. When he enters school, the language is learned in order develop the language skills he learned. In other words, he learns the rules of grammar which represent the controls for the syntax of sentences, and so he starts making sentences by himself without the help of dictation method.

\section{SENTENCE StRUCtURE IN LANGUAGE}

All human languages consist of sentences, but they vary in the sentence structure, as it shows the physical nature of the sentence and explains the elements from which the sentence is made up [10]. The word order has to do with the arrangement of the grammatical structure of language, for human languages differ in the order of words, that is to say, the way sentences are structured of the language fundamental components. This is a feature which distinguishes a language from another as seen by linguists. One of the divisions of these scholars of languages is based on the way sentences are structured in the discourse of a particular human group. They divide languages into various types according to the succession of a sentence (Subject), (Verb) and (Object) as well as the (complements), which is regarded as a distinctive feature of a particular language. A sentence, any sentence, consists basically of a verb, a subject, and an object, with other additions [11]. There are six patterns that represent the word order in a language: they are add (SVO) subject, verb, object, (SOV) subject, object, verb, (VSO) verb, subject, object, (VOS) verb, object, subject, (OSV) object, subject, verb, and (OVS) object, verb, and subject. The overwhelming majority of the world's languages follow either SVO or SOV patterns [12]. Some languages have a fixed word order, and others have a free unfixed word order [13].

The word order in the human language is arranged on several structures that consist of the subject $(\mathrm{S})$, the object $(\mathrm{O})$, and the verb $(\mathrm{V})$, and there are six structures for word order. Languages have been classified into categories according to the word order structure that can be found in human languages [14] as in table (1). There is a study on the classification of languages and distribution of word order in the map of the 
world as in the world Atlas of Linguistic Structures Online [15].

TABLE I. WORD ORDER AND DISTRIBUTION IN HUMAN LANGUAGES

\begin{tabular}{|c|c|c|c|}
\hline & "She him loves." & $45 \%$ & $\begin{array}{c}\text { Pashto, Latin, } \\
\text { Japanese, Afrikaans }\end{array}$ \\
\hline SOV & "She loves him." & $42 \%$ & $\begin{array}{c}\text { English, Hausa, } \\
\text { Mandarin, Russian }\end{array}$ \\
\hline VSO & "Loves she him." & $9 \%$ & $\begin{array}{c}\text { Biblical } \\
\text { Hebrew, Irish, } \\
\text { Filipino, Tuareg }\end{array}$ \\
\hline VOS & "Loves him she." & $3 \%$ & $\begin{array}{c}\text { Malagasy, } \\
\text { Baure }\end{array}$ \\
\hline OVS & "Him loves she." & $1 \%$ & $\begin{array}{c}\text { Apalaí?, } \\
\text { Hixkaryana? }\end{array}$ \\
\hline
\end{tabular}

\section{A. Sentence Structure in the Arabic Language}

The Arabic language is different from other languages, where the sentence has various word orders like SVO and VSO. The Arabic language is rich in grammatical structures and is different from English in that the word order is not fixed. When the word order in the sentence changes it will not affect the sentence meaning unlike the English language, as can be shown in the examples [16].

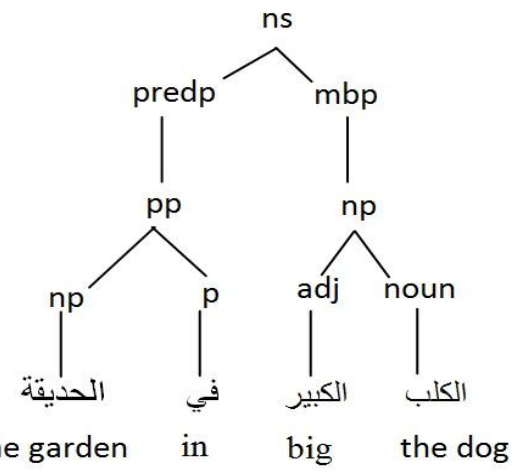

Fig. 2. Sentence Structure in Arabic, An Example of nominal sentence

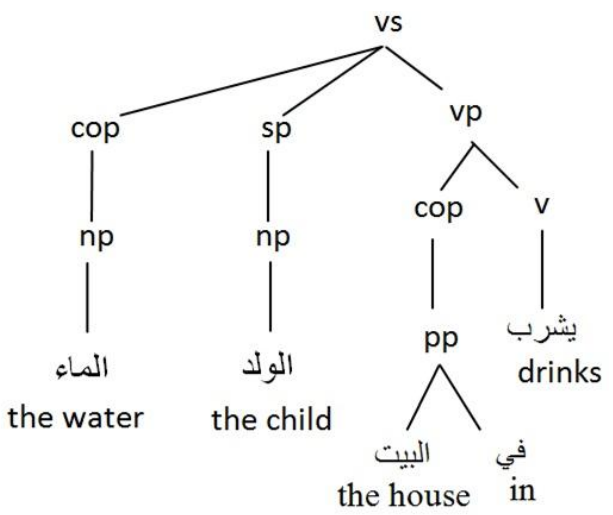

Fig. 3. Sentence Structure in Arabic ,An Example of verbal sentence

The Arabic language is characterized by the relatively free order of words; the Arabic sentence is diverse by the several word order forms such as VSO, SVO, and VOS, as in the examples in (Table 1) [17].

\section{B. Sentence Structure in the Russian Language}

The word order in Russian is not fixed; the sentence in the Russian language may be composed of a combination of the word order, that is to say, the place of the subject, the verb and object of the sentences can be changed without any change in the meaning of the sentences [18]. Flexibility in the Russian language means that the sentence admits the six-word order structures (SVO, SOV, VSO, VOS, OSV, and OVS) without any change in the meaning of the sentence. For example, in the English sentence "the boy read the paper" if we make all the possible six orders of the sentence in the Russian language, there will be no change in meaning, as in Table (2) below [19]:

TABLE II. COMPARISON BETWEEN SENTENCES IN RUSSIAN AND ENGLISH

\begin{tabular}{|l|c|l|}
\hline \multicolumn{1}{|c|}{ Russian language } & $\begin{array}{c}\text { Order } \\
\text { word }\end{array}$ & \multicolumn{1}{|c|}{ English language } \\
\hline Коля купил машину & S V O & $\begin{array}{l}\text { Kolya Bought the car } \\
\text { (neutral) }\end{array}$ \\
\hline Коля машину купил & S O V & Kolya BOUGHT the car \\
\hline Купил Коля машину & V S O & Kolya did bought the car \\
\hline Купил машину Коля & V O S & KOLYA bought the car \\
\hline Машину Коля купил & O S V & the car, Kolya BOUGHT it \\
\hline Машину купил Коля & O V S & $\begin{array}{l}\text { The car, it was Kolya who } \\
\text { bought it }\end{array}$ \\
\hline
\end{tabular}




\section{Sentence Structure in the English language}

The sentence structure of the English language consists of a subject, a verb and an object (SVO) known as (canonical word order). Word order in the English language is fixed, since the subject comes first in the English sentence [20], like other languages which consist of the nominal sentence and the verbal sentence. The structure of grammatical sentences is shown in (Figure 4) [21]:

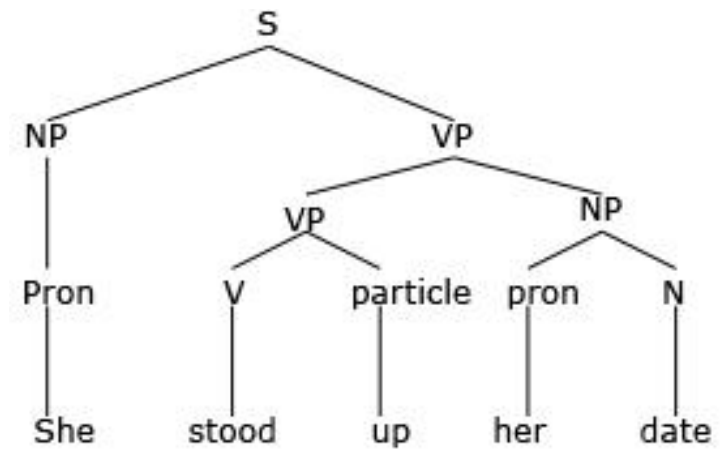

Fig. 4. Sentence Structure in the English Language

\section{CRITICISM}

First, when Chomsky proposed the universal grammar and child language acquisition theory he did not study languages, that is, he did not take samples from several languages, but he thought of this language only at the level of the nature of the English language, and that is why the rule was void of analysis, evidence, and application as forms of proof of their existence. Languages are similar it in general, but in particular, they are different, as already discussed in previous sections of this paper. Second, this grammar and theory were proposed on the principle of thought and theory analysis which are far from the application. Third, language is based on knowledge and skills just like other sciences and skills. So, is there a part of the brain that is devoted to each science and skill, for music, art and sports? All science and skills are learned and acquired through practice, education, and application; if all people acquire language innately and learn everything by instinct, it will be a sign that the level of knowledge among all human beings is equal.

The Universal grammar and child language acquisition were not received warmly since they were initiated by Chomsky. Rather, they have received criticism by linguists. This criticism will be identified and discussed below.

Many linguists opposed the universal grammar theory, including Jeffrey Sampson, who talked about the theory as an incorrect or false one and described it as unrealistic observations and views for language. There are many opinions which suggested that there is no basis for the universal grammar theory [22] and that it does not have any evidence or proof, including the underlying items. This was Ray Daniel Everett's view, but some others denied the existence of universal grammar altogether and advocated that it was unrealistic, and there was no evidence to prove its existence. There are several factors that play a role in the organization of communication and dialogue, and this is what was issued before [23].
There is a lot of criticism and among the most prominent critics is Jean Piaget with whom Chomsky has a debate that the theory lacks a concrete reality, where one can acquire knowledge of a certain thing through practice, experience and comprehension. Chomsky suggests acquiring knowledge of language by providing general rules for all languages. However, Jean Piaget expressed his opinion that Chomsky's hypothesis could not be accepted by the premise of the "fixed innate nucleus" because he neither interpreted nor proved it.

Ray Skinner had well-known views on language acquisition. He stated that knowledge is acquired through the environmental and reinforcement, where children learn language through input which is "the environmental conditions as a result of training for by caregivers [24]. People around the child have an influence on the acquisition of language. The scholar Tomasello, who is one of Chomsky's critics, also shows his opinion. He states that children acquire language by understanding how to use the language of others around them [25].

\section{FINITE STATE AUTOMATON AND UNIVERSAL GRAMMATICAL RULES}

All human languages consist of words, but these words are subject to an arranged and tidy grammatical order since each language adopts a particular word order as has been discussed in the previous sections of this paper. Finite state automaton leads to the correct meaning of the sentence. If the arrangement is not consistent with the approved order of the language, the meaning of the sentence would be incorrect. Accordingly, the general rules are not consistent with all languages. In this paper, a finite state automaton was set up; cases represent the subject $(\mathrm{S})$ the verb $(\mathrm{V})$ and the object $(\mathrm{O})$. A sentences in several languages (Arabic and English and Russian) will be tested. The finite state automaton represents here the role of the general rules in order to see the compatibility of the general rules with the languages.

The word order in the English language plays a key role because the grammatical meaning depends on the order of words. In the Russian sentence, if we change the position of the words within the sentence, the general meaning of the sentence will not change. The Russian language is compatible with all arrangements, that is to say, it is free in the arrangement, and so is the Arabic language which has a free feature of free word order. Arabic is compatible with the range arrangements SVO, VSO, VOS and OVS, for if the position of the subject in the sentence is changed the meaning remains the same, unlike the English language where the meaning changes, as shown in the examples [26].

A finite state automaton acts as the universal grammar in this paper. In figure 5 a finite state automaton accepts languages that are compatible with all word orders such as Arabic and Russian while the finite state automaton in Figure 6 accepts all languages that comply with the word order that begins with the subject such as English. Table (3) shows the application of sentences of different languages to the finite state automaton and cases of acceptance and rejection in terms of the word order of a language and the correct meaning of the sentence. 


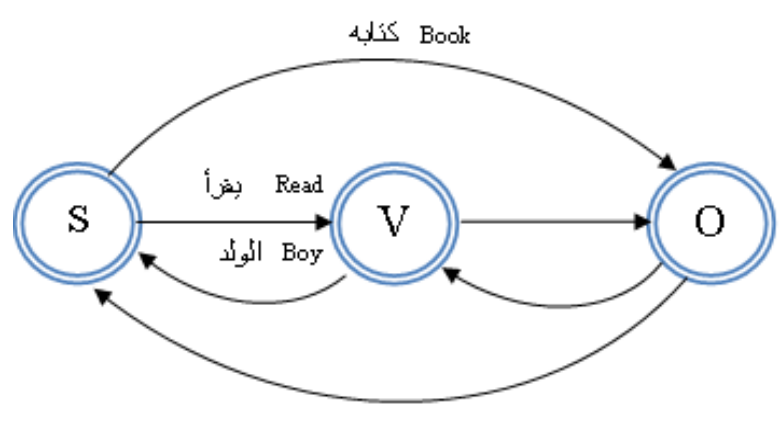

Fig. 5. finite-state automaton, multi-lingual

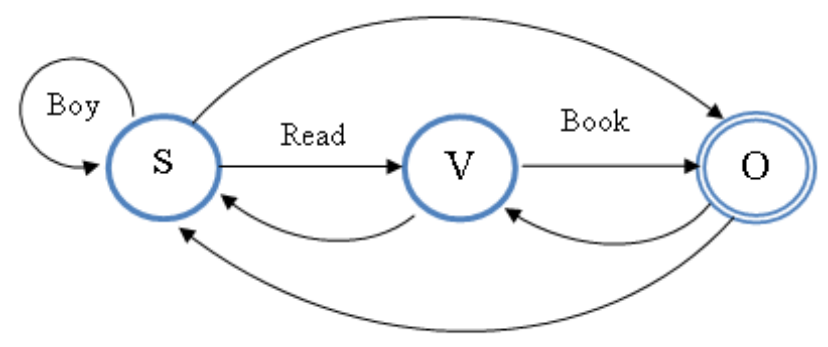

Fig. 6. finite-state automaton, English

We note that there is a difference between languages in the structure of sentences which adjusts the structure of sentences in the language, that is the language rules, and in light of this we conclude that languages share the components of words and differ in their structure and rules. Nevertheless, it is difficult to find general rules that represent all languages, that is, each language is unique by its rules and characteristics. As shown in the table (4), the derivation of sentences from the same rules is different and some sentences are no longer correct regarding of structure and meaning.

TABLE III. RESUlts OF THE APPLICATION OF SENTENCES ON THE FINITE STATE AUTOMATON

\begin{tabular}{|c|c|c|c|}
\hline $\begin{array}{c}\text { The final } \\
\text { status } \\
\text { (meaning of } \\
\text { the sentence) }\end{array}$ & $\begin{array}{l}\text { Order } \\
\text { Word }\end{array}$ & Language & Sentence \\
\hline تقبل & SVO & العربية & الولا يقرأ الكتاب \\
\hline تقبل & SVO & الانجليزية & The boy reads the book \\
\hline تقبل & SVO & 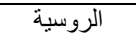 & Мальчик читает книгу \\
\hline تقبل & $\mathrm{VSO}$ & العربية & يقرأ الولد كتابه \\
\hline لاتقبل & VSO & الانجليزية & Read the boy the book \\
\hline تقبل & VSO & الروسية & Читайте мальчику книгу \\
\hline تقبل & OVS & العربية - العزية & الكتاب يقر اه الولد \\
\hline لاتقبل & OVS & الانجليزية & The book reads the boy \\
\hline تقبل & OVS & الروسية & Книга читать мальчика \\
\hline
\end{tabular}

TABLE IV. SENTENCE DERIVATION FROM RULES BY WORD ORDER

\begin{tabular}{|l|l|l|l|l|}
\hline $\begin{array}{l}\text { Order } \\
\text { Word }\end{array}$ & Grammar Rules & $\begin{array}{l}\text { English } \\
\text { language }\end{array}$ & $\begin{array}{l}\text { Arabic } \\
\text { Language }\end{array}$ & $\begin{array}{l}\text { Russian } \\
\text { Language }\end{array}$ \\
\hline
\end{tabular}

\begin{tabular}{|c|c|c|c|c|}
\hline SVO & 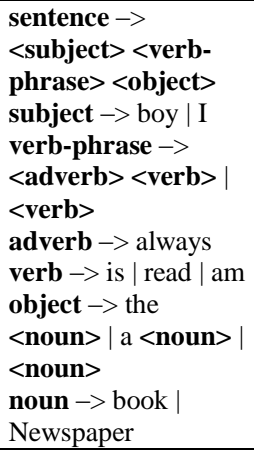 & $\begin{array}{l}\text { The boy } \\
\text { reads the } \\
\text { book }\end{array}$ & الولائاب أل الكتر & $\begin{array}{l}\text { Мальчик } \\
\text { читает } \\
\text { книгу }\end{array}$ \\
\hline VSO & 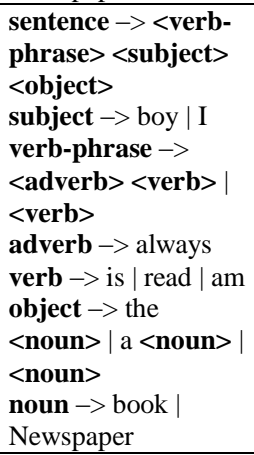 & $\begin{array}{l}\text { Read the } \\
\text { boy the } \\
\text { book }\end{array}$ & كتابه أولا & $\begin{array}{l}\text { Читайте } \\
\text { мальчику } \\
\text { книгу }\end{array}$ \\
\hline VOS & 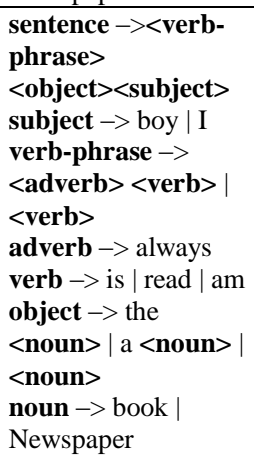 & $\begin{array}{l}\text { Read the } \\
\text { book boy }\end{array}$ & الولد أ الكتابه & $\begin{array}{l}\text { Читайте } \\
\text { мальчику } \\
\text { книгу }\end{array}$ \\
\hline OVS & $\begin{array}{l}\text { sentence }-><\text { object }> \\
\text { < verb-phrase> } \\
\text { < subject> } \\
\text { subject } \rightarrow \text { boy } \mid \text { I } \\
\text { verb-phrase }-> \\
\text { <adverb> <verb> | } \\
\text { <verb> } \\
\text { adverb }->\text { always } \\
\text { verb } \rightarrow \text { is | read | am } \\
\text { object }->\text { the } \\
\text { <noun> | a <noun> | } \\
\text { <noun> } \\
\text { noun } \rightarrow \text { book | } \\
\text { Newspaper }\end{array}$ & $\begin{array}{l}\text { The book } \\
\text { reads the } \\
\text { boy }\end{array}$ & الكتاب يقر اه & $\begin{array}{l}\text { Книга } \\
\text { читать } \\
\text { мальчика }\end{array}$ \\
\hline
\end{tabular}

\section{CONCLUSION AND FUTURE WORK}

Several languages have been studied as case studies regarding of structure, word order, and the rules in order to know the compatibility of the universal grammar rules with those languages. We conclude that there is a problem in compatibility between the rules of universal grammar and human languages, and this shows that the child learns the mother language in the surrounding environment by acquiring skills and knowledge. This has between shown by linguists where the theory was criticized, and a finite state automaton has been set up which acts as a language device that has a universal grammar to examine languages compatibility. By 
citing criticism, analysis and discussion, the universal grammar rules are having a trouble of incompatibility with human languages; each language has its special rules, but which share other languages only the elements of verb, subject, and object.

In the future, the theory of transformational generative grammar and probability theory will be applied, by choosing some words and forming sentences in several languages. These sentences will be checked as to whether they comply with the rules of languages in terms of meaning and structure. The percentage of the sentence accuracy for each language will be calculated, which gives an indication that there is no universal grammar for all languages.

\section{REFERENCES}

[1] C. Brown , P. Hagoort, and M. Ter Keurs , "Electrophysiological signatures of Visual Lexical Processing: Open- and Closed-Class Words," Journal of Cognitive Neuroscience, vol. 11, pp. 261 - 281, May 1999.

[2] B. Burke, "Rituals and beliefs ingrained in world language pedagogy: Defining deep structure and conventional wisdom," Journal of Language Teaching and Research, vol. 2, pp. 1-12, January 2011.

[3] Fiona Cowie Innateness and Language, http://plato.stanford.edu/entries/innateness-language/,Jan 2008.

[4] C. Derek, J. Keith, and J. Daniel, "Darwin's mistake: Explaining the discontinuity between human and nonhuman minds." Behavioral and Brain Sciences ,vol 31, pp. 109-130, April 2008.

[5] E. Kandel, E-Study Guide for Principles of Neural Science, Cram101 Textbook Reviews , 5th Edition,2013.

[6] V. Cook., Multilingual Universal Grammar as the norm. In I. Leung (ed.) Third Language acquisition and Universal Grammar, Bristol: Multilingual Matters, pp. 55-70,2009.

[7] B. Rowe, D. Levine, "A Concise Introduction to Linguistics",ch8, pp. 233, Routledge 2015.

[8] Dąbrowska, E. (2015). What exactly is Universal Grammar, and has anyone seen it?. Frontiers in psychology, 6.

[9] Samúelsdóttir, B. (2015). The Innateness Hypothesis: Can Knowledge of Language be Inborn?.

[10] A. Akmajian, A. Demer, and K. Farme , M. Harnish "Linguistics: An Introduction to Language and Communication," pp.153-604, MIT Press 2001.

[11] D. Carroll,"e-Study Guides for: Psychology of Language," Cram101 Textbook Reviews, 2013.
[12] D. Kemmerer,'The Cross-Linguistic Prevalence of SOV and SVO Word Orders Reflects the Sequential and Hierarchical Representation of Action in Broca's Area," Language and Linguistics Compass, vol 6, pp.50-66, January 2012.

[13] I. Laka , K. Erdocia, "Linearization Preferences Given "Free Word Order" Subject Preferences Given Ergativity: A Look At Basque," Of grammar, words, and verses, In honor of Carlos Piera, Ch 6, pp.115$140,2012$.

[14] F. Meyer, "Introducing English Linguistics International Student Edition," Cambridge University Press 2010.

[15] Dryer, Matthew S. \& Haspelmath, Martin (eds.) 2013. The World Atlas of Language Structures Online.

[16] Leipzig: Max Planck Institute for Evolutionary Anthropology.(Available online at http://wals.info, Accessed on 2016-01-15.)

[17] M. Al Aqad, "Syntactic analysis of Arabic adverb's between Arabic and English: X bar theory," International Journal of Language and Linguistics, vol 1(3), pp.70-74, August 2013.

[18] H. Bassam, M. Asma, and O. Nadim, T. Abeer," Formal description of Arabic syntactic structure in the framework of the government and binding theory," Computación y Sistemas, vol 18(3), pp. 611-625, sep 2014.

[19] L. Isurin, “ Cross Linguistic Transfer in Word Order: Evidence from L1 Forgetting and L2 Acquisition," Proceedings of the 4th International Symposium on Bilingualism, pp.1115-1130. Somerville, MA: Cascadilla Press 2005.

[20] A.Kharitonova, " Lexical transfer and avoidance in the acquisition of English phrasal verbs," MA Thesis, University of Oslo,May 2013.

[21] K. Christianson, F. Ferreira, "Conceptual accessibility and sentence production in a free word order language (Odawa) ," International Journal of Cognitive Science, Elsevier Cognition vol 98, pp. 105135,2005 .

[22] N. Oostdijk, "Corpus Linguistics and the Automatic Analysis of English,” pp-89-267, Rodopi 1991.

[23] J. Hurford, "Nativist and Functional Explanations in Language Acquisition," Logical Issues in Language Acquisition, pp.88-136. 1995.

[24] Universal Grammar, (n.d.). In Wikipedia. Retrieved 10 February 2016from https://en.wikipedia.org/w/index.php?title=Universal_Gramm ar\&oldid=704299963.

[25] B. Samúelsdóttir," The Innateness Hypothesis Can Knowledge of Language be Inborn?," http://hdl.handle.net/1946/20344,Thesis, University of Iceland, 2015.

[26] all about linguistics to discover and understand, https://sites.google.com/a/sheffield.ac.uk/all-aboutlinguistics/branches/language-acquisition/who-studies-languageacquisition, University of Sheffield 2015. 